\title{
PENGARUH FACEBOOK TERHADAP PRESTASI BELAJAR FIKIH SISWA KELAS VII DI MTS NEGERI 2 KOTA TANGERANG
}

\author{
Abdul Basyit \\ abdulbasyit@umt.ac.id \\ (Fakultas Agama Islam, Universitas Muhammadiyah Tangerang) \\ Miftahul Zanah \\ Miftahul54@gmail.com \\ (Program Studi Pendidikan Agama Islam, Fakultas Agama Islam, Universitas \\ Muhammadiyah Tangerang)
}

\begin{abstract}
Abstrak;
Dalam dunia pendidikan media sosial memberikan kemudahan berinteraksi, mencari informasi, memberikan peranan positif serta ada yang memberikan pesanan negative. Manfaat facebook ditinjau sebagai KBM yaitu memberikan informasi positif untuk siswa dalam memberikan tugas melalui pesan atau grup facebook. Guru melakukan berbagai pengaturan privasi di facebooknya agar hanya bisa diakses oleh siswa, guru menguplod ringkasan materi pelajaran di halaman facebook, membahas soal-soal yang dianggap penting. Berdasarkan penelitian ini menyatakan adanya Pengaruh facebook terhadap prestasi belajar siswa kelas VII pada mata pelajaran fikih di MTs Negeri 2 Kota Tangerang.
\end{abstract}

\section{Kata Kunci: facebook, Prestasi Belajar, fikih.}

\section{Abstract;}

In the world of education, social media makes it easy to interact, find information, give a positive role and some give negative orders. The benefits of Facebook are viewed as teaching and learning activities, which is to provide positive information for students in giving assignments through messages or Facebook groups. The teacher makes various privacy settings on Facebook so that it can only be accessed by students, the teacher uploads a summary of the subject matter on the Facebook page, discusses questions that are considered important. Based on this research, it states that there is an effect of Facebook on the learning achievement of grade VII students in fiqh subjects at MTs Negeri 2 Kota Tangerang.

Keywords: Facebook, Learning Achievement, fiqh.

\section{A. Pendahuluan}

Pendidikan adalah usaha sadar yang dilakukan oleh keluarga, masyarakat dan pemerintah melalui kegiatan bimbingan, pengajaran, dan latihan, yang berlangsung di sekolah dan di luar sekolah sepanjang hayat, pendidikan adalah pengalamanpengalaman belajar terprogram dalam bentuk pendidikan formal, non formal dan informal di sekolah dan luar sekolah yang berlangsung seumur hidup yang bertujuan optimalisasi perimbangan kemampuankemampuan individu, agar dikemudian hari dapat memainkan peran hidup secara tepat. ${ }^{1}$ Pengertian pendidikan bahkan lebih diperluas cakupannya sebagai aktivitas dan fenomena. Pendidikan sebagai aktivitas berarti upaya secara sadar dirancang untuk

${ }^{1}$ Redja Mudyaharjo, Pengantar Pendidikan (Jakarta: PT.Raja Grafindo, 2001), h. 11. 
membantu seseorang atau sekelompok orang dalam mengembangkan pandangan hidup, sikap hidup, dan keterampilan hidup, baik yang bersifat manual maupun mental dan sosial. $^{2}$ Tujuan pendidikan merupakan perpaduan tujuan-tujuan pendidikan yang bersifat pengembangan kemampuan-kemampuan pribadi secara optimal dengan tujuan-tujuan sosial yang bersifat manusia seutuhnya yang dapat memainkan peranannya sebagai warga dalam berbagai lingkungan persekutuan hidup dan kelompok sosial. Penggunaan internet pada saat ini sangat mudah dijangkau oleh siapapun, dimanapun, dan kapanpun. Contohnya sekarang ini hampir semua alat komunikasi seperti hand phone pun sudah memiliki aplikasi yang memudahkan penggunanya untuk menjelajahi internet. Bahkan kemajuan teknologi tersebut menyebabkan munculnya berbagai macam situs jejaring sosial, seperti, facebook whatsapp, instagram dan lain-lain. Media social merupakan salah satu kecanggihan teknologi yang sebagai tempat komunikasi jejaring sosial dunia maya. Dari media sosial ini para penggunanya dapat berinteraksi dan mencari informasi dengan pengguna yang lain dalam cakupan yang besar dan meluas. Dengan adanya media sosial ini sangatlah memberikan kemudahan untuk berinteraksi dan mencari informasi, dari media social ini ada yang memberikan peranan positif serta ada yang memberikan pesanan negative. Mulai dari usia anak-anak sampai usai dewasa menggunakan media sosial. ${ }^{3}$ Munculnya media sosial di internet membuat para pengguna memiliki dunia sendiri, terutama pada para siswa, sehingga mereka kurang

${ }^{2}$ Redja Mudyaharjo, Pengantar Pendidikan (Jakarta: PT.Raja Grafindo, 2001), h. 11.

${ }^{3}$ Rully Nasrullah, Media Sosial: Perspektif Komunikasi, Budaya, dan Sosioteknologi, (bandung, Simbiosa Rekatama Media,2015), h. 47. peduli dengan orang lain dan lingkungan sekitar. Serta membuat para siswa kurangnya bersosialisasi dengan lingkungan sekitar karena mereka lebih asyik dengan teman ataupun komunikasi yang ada di internet dan mereka lebih mementingkannya dibandingkan dengan yang ada di sekitar mereka. ${ }^{4}$ Dengan adanya media sosial ini sangatlah berpengaruh dalam prestasi belajar siswa, kebanyakan dari siswa lupa waktu untuk belajar, sehingga minat belajar siswa sangatlah rendah. Siswa lebih asyik dengan media sosial dibandingkan mengerjakan tugas yang diberikan guru, sehingga apa yang diajarkan oleh guru siswa cenderung tidak mengerti. ${ }^{5}$

Situs media sosial di internet bermacam-macam bentuknya, namun banyak yang sering dikenal dan digunakan para remaja jaman sekarang salah satunya adalah facebook, mereka mengganggap bahwa facebook adalah salah satu media sosial yang sangat penting dan yang sering diminati oleh semua kalangan. ${ }^{6}$ Facebook adalah situs pertemanan popular yang berasal dari Amerika. Facebook menerima semua pengguna yang berusia lebih dari tiga belas tahun dan memiliki sebuah alamat email yang valid. Sebuah alamat email yang valid akan diverifikasi oleh facebook, pengguna menerima semua email pada alamat email yang didaftarkan dan mengklik link yang ada pada email untuk membuktikan bahwa alamat email tersebut

\footnotetext{
${ }^{4}$ Nurul Anisa. Penggunaan Jejaring Sosial "facebook" Terhadap Minat Belajar PAI Siswa kelas VIII SMP Negeri Yogyakarta, Skripsi, Jurusan Pendidikan Agama Islam Fakultas Ilmu Tarbiyah dan Keguruan UIN Sunan Kali jaga Yogyakarta, 2013.

${ }^{5}$ Priyatna Haris, Sukses di Era Facebook, (Bandung: Kelompok pustaka hidayah), h. 25.

${ }^{6}$ Rulli, Nasrullah, Media social "perspektif komunikasi, budaya, dan Sosioteknologi”, h. 30
} 
benar adanya. Setelah itu pengguna bisa menikmati semua layanan facebook gratis. $^{7}$

Facebook merupakan situs website jejaring sosial di mana para pengguna dapat bergabung dalam sebuah komunikasi seperti kota, kerja, sekolah dan daerah untuk melakukan koneksi dan berinteraksi dengan orang lain. ${ }^{8}$ Pada saat ini facebook menjadi satu-satunya situs yang paling popular dan sukses memiliki para pengguna. Orang juga dapat menambahkan daftar kontak teman mereka, mengirim pesan, dan memperbarui profil pribadi agar orang lain dapat melihat tentang dirinya. ${ }^{9}$ Dalam dunia pendidikan media sosial memberikan dampak yang positif serta memberikan dampak yang negative. Dampak positif dengan adanya internet siswa bisa mencari informasi dan berkomunikasi dengan luas, dampak dari negative media sosial bagi pendidikan adalah menurunnya motivasi siswa serta prestasi belajar siswa dan malasnya akan belajar. Prestasi belajar adalah hasil belajar yang dapat dicapai oleh individu setelah melakukan serangkaian proses belajar. Prestasi belajar merupakan satu masalah yang sangat penting karena dengan kehadiran prestasi belajar dapat memberikan suatu kepuasan apalagi bagi peserta didik yang bersekolah. ${ }^{10}$

\footnotetext{
${ }^{7}$ Rulli, Nasrullah, Media social "perspektif komunikasi, budaya, dan Sosioteknologi”, h. 30

${ }^{8}$ Rulli, Nasrullah, Media social "perspektif komunikasi, budaya, dan Sosioteknologi”, h. 30

${ }^{9}$ Hasan Febriyanto Fuad, "Efektivitas Jejaring Sosial Facebook Sebagai Media Dakwah (Studi Terhadap Facebook Yusuf Mansur Network)", Skripsi, Jurusan Komunikasi dan Penyiaran Islam Fakultas Dakwah dan Komunikasi UIN, Sunan Kalijaga Yogyakarta 2013.

${ }^{10}$ Hasan Febriyanto Fuad, "Efektivitas Jejaring Sosial Facebook Sebagai Media Dakwah (Studi Terhadap Facebook Yusuf Mansur Network)", Skripsi, Jurusan Komunikasi dan Penyiaran Islam Fakultas Dakwah dan Komunikasi UIN, Sunan Kalijaga Yogyakarta 2013.
}

Dari Uraian diatas maka dalam tulisan ini akan dibahas langkah-langkah antisipasi jika facebook digunakan oleh siswa/siswi kelas VII di MTs Negeri 2 Kota Tangerang. Manfaat facebook jika ditinjau sebagai media dalam KBM siswa/siswi kelas VII di MTs Negeri 2 Kota Tangerang, dan pengaruh prestasi belajar siswa/siswi kelas VIII di MTs Negeri 2 Kota Tangerang.

\section{B. Kajian Pustaka}

1. Facebook

a. Pengertian Facebook

Facebook adalah situs pertemanan popular yang berasal dari Amerika. Facebook menerima semua pengguna yang berusia lebih dari tiga belas tahun dan memiliki sebuah alamat email yang valid akan diverifikasi oleh facebook, pengguna menerima sebuah email pada alamat email yang didaftarkan dan mengklik link yang ada pada email untuk membuktikan bahwa alamat email tersebut benar adanya. ${ }^{11}$

Menurut Wati dan Rizky facebook merupakan jejaring sosial (social network) yang bisa dimanfaatkan oleh para pengguna untuk saling mengenal dan berkomunikasi dalam berbagai keperluan dan juga bersifat rekresi. ${ }^{12}$ Facebook adalah situs website jejaring sosial di mana para pengguna dapat bergabung dalam sebuah komunitas seperti kota, kerja, sekolah, dan daerah untuk melakukan koneksi dan berinteraksi dengan orang lain.

b. Fungsi Media Sosial

Ketika kita mendefinisikan media sosial sebagai system komunikasi maka kita harus mendefinisikan fungsi-fungsi terkait dengan system komunikasi, yaitu:

1) Administrasi. Pengorganisasian profil

\footnotetext{
${ }^{11}$ Sartika Kurniali, Step By Step Facebook, (Jakarta: PT Elex Media Komputindo,2009, h. 4

12 Andi Wicaksono, Bahaya facebook, (Solo: Serikat Penerbit Islam, 2009), h. 12
} 
karyawan perusahaan dalam jaringan sosial yang relevan dan relative di mana posisi pasar anda sekarang. Pembentukan pelatihan kebijakan media sosial, dan pendidikan untuk semua karyawan pada penggunaan media sosial. ${ }^{13}$

2) Mendengarkan dan Belajar. Pembuatan system pemantauan untuk mendengar apa yang pasar anda inginkan, apa yang relevan dengan mereka. ${ }^{14}$

3) Berpikir dan Perencanaan. Dengan melihat tahap 1 dan 2, bagaimana anda akan tetap di depan pasar dan bagaimana anda berkomunikasi ke pasar. Bagaimana teknologi sosial meningkatkan efisiensi operasional hubungan pasar.

4) Pengukuran. Menetapkan langkahlangkah efektif sangat penting untuk mengukur apakah metode yang digunakan, isi dibuat dan alat yang anda gunakan efektif dalam meningkatkan posisi dan hubungan pasar anda. ${ }^{15}$

c. Sejarah Facebook

Pada saat pengembangannya,

Zuckerberg tahu bahwa tidak mudah untuk membuatnya langsung terkenal. Terutama dengan adanya situs pertemanan lain yang mapan membuat semuanya menjadi sulit. Oleh karenanya, The Facebook didirikan sehingga hanya orang tertentu yang bisa bergabung. ${ }^{16}$ Pertama kali didirikan tanggal 4 Febuari 2004 facebook hanya terbatas untuk kalangan dari Universitas

\footnotetext{
${ }^{13}$ Nasrullah, Rully, media sosial "perspektif komunikasi, budaya, dan sosioteknologi”, h.10

${ }^{14}$ Sardiman, Interaksi dan Motivasi Belajar Mengajar, (Jakarta: Rajawali Pers), h. 11

15 Jaya Putra, Pengertian Media Sosial Peran dan Fungsinya, artikel di akses pada 28 Juli 2016 dari https://ptkomunikasi. wordpress.com /2012/06/11/pengertian-media-sosial-peran-sertafungsinya//

${ }^{16}$ Martono, Nanang, "Metode Penelitian Sosial (Konsep-konsep kunci)" (Jakarta, PT. Raja Grafindo Persada).
}

Harvard dan lalu berkembang ke kampus Stanford. Semua pengguna yang mendaftar pada orang dengan alamat email dari kampus yang didukung.

2. Dampak Penggunaan Facebook

Facebook saat ini salah satu jejaring sosial yang banyak digemari di beberapa Negara salah satunya di Indonesia. Mulai dari anak-anak, dewasa bahkan yang tua sekalipun. Indonesia sendiri saat ini telah menempati di urutan ke tiga pengguna facebook terbesar di dunia setelah Amerika Serikat dan India. Dalam perkembangannya tentunya setiap teknologi mempunyai efek baik dan buruk, untuk itu bagi si user harus mengetahui dampak positif dan negatif dari suatu teknologi itu sendiri. ${ }^{17}$ Dampak negatif dari facebook yaitu mengganggu pekerjaan, betasan ranah pribadi yang menjadi kabur, interaksi sosial berkurang, dapat menimbulkan kesalahpahaman antar pengguna facebook, penipuan, mengganggu kesehatan, lupa waktu, pencurian identitas, kerusakan fisik juga sangat mungkin terjadi, memicu anak untuk melakukan criminal, lenyapnya ungkapan tradisional, dan dapat terjadi kesalah pahaman.

3. Kelebihan Facebook

Berikut ini adalah beberapa kelebihan dari facebook, di antaranya:

a. Walau dengan desain situs yang sederhana dan terkesan minimalis, facebook menggunakan bahasa pemrograman Ajax yang bisa membuat kita menjelajahi facebook lebih nyaman.

b. Facebook memiliki jumlah pengguna yang besar dan beragam dengan segmen terbesar dari orang muda sehingga tepat untuk anda yang mencari teman dan ingin berbagi dengan teman-teman

\footnotetext{
${ }^{17}$ Bunga Novana, Dampak Positif dan Negatif Penggunaan Facebook, artikel diakses pada tanggal 5 April 2016, dampak positif dari http://bunganovana.blogspot.co.id//
} 
anda.

c. Facebook memiliki aplikasi yang unik dan beragam, mulai dari permainan, simulasi saham.

d. Anda bisa mengetahui apakah ada teman anda yang sedang online di facebook pada saat anda juga berada di sana.

e. Anda bisa langsung chat di facebook bersama anda yang sedang online juga. $^{18}$

4. Manfaat Facebook

a. Tempat informasi hasil karya penelitian seperti Hasil Penelitian Tindakan Kelas (PTK).

b. Membentuk komunitas pendidikan.

c. Memberi informasi penting untuk siswa seperti tes CPNS untuk alumni.

d. Wahana untuk memberikan pesan positif untuk siswa.

e. Tempat memberikan tugas guru kepada muridnya.

f. Tempat melaporkan tugas siswa.

g. Tempat memberikan informasi berupa kisi-kisi soal.

h. Sarana untuk memberikan dukungan kepada temannya yang ikut lomba.

i. Tempat pengumuman nilai hasil ulangan. ${ }^{19}$

5. Langkah-Langkah Antisipasi Penyalah Gunaan Pemakaian Facebook

a. Setiap guru dan disetiap sekolah diwajibkan memiliki akun facebook baru, khusus untuk program ini.

b. Guru bersangkutan melakukan berbagai settingan/pengaturan privasi di facebooknya agar hanya bisa diakses oleh siswa / siswi kelas yang ia tanganin.

c. Guru wajib menguplod ringkasan materi pelajaran hari ini di halaman facebook. Dan membahas soal-soal yang dianggap

\footnotetext{
${ }^{18}$ Sartika Kurniali. Step by Step Facebook..., h. 17

19 Priyatna Haris, Sukses di Era Facebook. (Bandung: Kelompok Pustaka Hidayah), h. 11
}

penting.

d. Setiap selesai mengajar di kelas, guru disarankan memberikan PR melalui halaman facebooknya.

e. Guru bisa menetapkan dan mengumumkan jadwal onlinenya ke siswa / siswinya.

f. Guru setiap saat bisa memberikan motivasi dan inspirasi terhadap siswa/siswinya dengan mengirimkan kata-kata, gambar, presentasi, atau tokoh-tokoh sukses yang bisa memotivikasi para siswa. ${ }^{20}$

6. Prestasi Belajar

a. Teori Prestasi Belajar

Prestasi adalah hasil dari suatu kegiatan yang telah dikerjakan, diciptakan baik secara individu atau kelompok. ${ }^{21}$ Menurut Purwodarminto prestasi adalah hasil sesuatu yang telah dicapai. ${ }^{22}$ Menurut Mas'ud Hasan Abdul Dahar prstasi adalah apa yang telah dapat diciptakan, hasil pekerjaan, hasil yang menyenangkan hati yang diperoleh dengan keuletan kerja. ${ }^{23}$ Sedangkan belajar adalah suatu proses usaha yang dilakukan seseorang untuk memperoleh suatu perubahan tingkah laku yang baru secara keseluruhan, sebagai hasil pengalamannya sendiri dalam berinteraksi dengan lingkungannya. ${ }^{24}$ Menurut Oemar Hamalik menyebutkan bahwa belajar merupakan memodifikasi atau memperteguh kelakuan melalui pengalaman. ${ }^{25}$ Menurut Whittaker, belajar

\footnotetext{
${ }^{20}$ Rosli Mohammad, Audit Komunikasi: Pendekatan dan Metode Asesmen Sistem Informasi, Komunikasi dalam organisasi, (Jakarta: Pranamedia Group, 2015).

21 Zaenal Arifin, Evaluasi Pembelajaran, (Jakarta: Dirjen Pendidkan Islam, 2009), h. 12.

${ }^{22}$ Syaiful Bahri Djamarah, Prestasi Belajar dan Kompetensi Guru, h. 19.

${ }^{23}$ Lida Susanti, Prestasi Belajar akademik dan Non Akademik, h. 6.

${ }^{24}$ Slameto, Belajar dan Faktor-faktor yang Mempengaruhi, h. 2.

${ }_{25}$ Slameto, Belajar dan Faktor-faktor yang Mempengaruhi, h. 2.
} 
adalah proses tingkah laku yang ditimbulkan atau diubah melalui latihan atau pengalaman. Sedangkan Kimble menjelaskan bahwa, belajar adalah perubahan relatif permanen dalam potensi bertindak, yang berlangsung sebagai akibat adanya latihan yang diperkuat.

b. Tipe-Tipe Prestasi Belajar

1) Tipe Prestasi Belajar Bidang Kognitif

Tipe-tipe prestasi belajar bidang kognitif mencakup tipe prestasi belajar pengetahuan hafalan (knowledge), tipe prestasi belajar pemahaman (comprehention), tipe prestasi belajar peranan (aplikasi), tipe prestasi belajar analisis, tipe prestasi belajar sistematis, tipe prestasi belajar evaluasi.

a) Pengetahuan hafalan merupakan terjemahan dari "knowledge" meminjam istilah Bloom. Pengetahuan ini mencakup aspek- aspek faktual dan ingatan (sesuatu hal yang harus diingat kembali) seperti batasan, peristilahan, pasal, hukum, bab, ayat, rumus, dan lain-lain.

b) Tipe prestasi belajar "pemahaman" lebih tinggi satu tingkat dari tipe prestasi belajar "pengetahuan hafalan". Pemahaman memerlukan kemampuan menangkap makna atau arti dari suatu konsep. Ada tiga macam pemahaman yaitu: 1). Pemahaman terjemahan, yakni kesanggupan memahami makna yang terkandung di dalamnya, 2). Pemahaman penafsiran, misalnya membedakan dua konsep yang berbeda, dan 3). Pemahaman ekstrapolasi, yakni kesanggupan melihat yang tertulis, tersirat dan tersurat, meramalkan sesuatu, dan memperluas wawasan.

c) Tipe prestasi belajar penerapan (aplikasi) merupakan kesanggupan menerapkan dan mengabstraksikan suatu konsep, ide, rumus, hukum dalam situasi yang baru. Misalnya memecahkan persoalan fara'id (pembagian harta pusaka dengan menggunakan rumus-rumus tertentu, menerapkan suatu dalil (al-Qur'anHadits) atau hukum Islam dan kaidahkaidah ushul fiqih dalam persoalan suatu umat.

d) Tipe prestasi belajar Analisis merupakan tipe prestasi belajar yang kompleks, yang memanfaatkan unsur tipe hasil belajar sebelumnya, yakni pengetahuan, pemahaman, dan aplikasi.

e) Sintesis merupakan lawan analisis. Analisis tekanannya adalah pada kesanggupan menguraikan suatu integritas menjadi bagian yang bermakna, sedangkan pada sintesis adalah kesanggupan menyatukan unsur atau bagian-bagian menjadi suatu integritas.

f) Tipe prestasi belajar evaluasi, Tipe prestasi belajar ini dikategorikan paling tinggi, mencakup semua tipe prestasi belajar yang telah disebut di atas. Dalam tipe prestasi belajar evaluasi, tekanan pada pertimbangan sesuatu nilai.

2) Tipe Prestasi Belajar Bidang Afektif Bidang afektif berkenan dengan sikap dan nilai. Sikap seseorang bisa diramalkan perubahan-perubahannya, Tipe prestasi belajar bidang afektif tampak pada siswa dalam berbagai tingkah laku, seperti atensi atau perhatian terhadap pelajaran, disiplin, motivasi belajar, menghargai guru dan teman, kebiasaan belajar, dan lain-lain.
3) Tipe Prestasi Belajar Bidang Psikomotorik

Tipe prestasi belajar bidang psikomotor tampak dalam bentuk keterampilan (skill), dan kemampuan bertindak seseong. Adapun tingkat keterampilan itu meliputi: 1). gerakan refleks (keterampilan pada gerakan yang sering tidak didasari karena sudah merupakan kebiasaan), 2). keterampilan pada gerakan-gerakan dasar, 3). 
Kemampuan perspektual termasuk di dalamnya membedakan visual, membedakan auditif motorik dan lain-lain, 4). kemampuan dibidang fisik seperti kekuatan, keharmonisan, dan ketepatan, 5). gerakan-gerakan yang berkaitan dengan skill, mulai dari keterampilan sederhana sampai pada keterampilan yang kompleks, dan 6). kemampuan yang berkenan dengan non decursive komunikasi seperti gerakan ekspresif dan interpretatif.

\section{Metode Penelitian}

Penelitian ini menggunakan metode penelitian kuantitatif. Menurut Sugiyono dalam bukunya metode penelitian kuantitatif, metode ini disebut metode kuantitatif karena data penelitian berupa angka-angka dan analisis menggunakan statistic $^{26}$ dengan demikian metode kuantitatif dapat diartikan sebagai metode penelitian yang berlandaskan pada filsafat positivisme, digunakan untuk meneliti pada populasi atau sampel tertentu, pengumpulan data menggunakan instrument penelitian, analisis dan bersifat kuantitatif atau statistic, dengan tujuan untuk menggambarkan dan menguji hipotesis yang telah ditetapkan. ${ }^{27}$ Populasi dan Teknik Pengambilan Sampel

1. Populasi adalah seluruh data yang menjadi perhatian kita dalam suatu ruang lingkup dan waktu yang kita tentukan. Jadi, populasi berhubungan dengan data, bukan manusianya. Kalau setiap manusia memberikan suatu data, maka banyaknya atau ukuran populasi akan sama dengan banyaknya manusia. ${ }^{28}$

\footnotetext{
${ }^{26}$ Sugiyono, Metode Penelitian Kuantitatif, (Bandung: Alfabeta), 2018. h. 15

${ }^{27}$ Suryani \& Hendryadi, Metode Riset Kuantitatif, Teori dan Aplikasi Pada Penelitian Bidang Manajemen dan Ekonomi Islam, (Jakarta: Pranamedia Group, 2015), h. 36

${ }^{28}$ S Margono, Metode Penelitian Pendidikan, (Jakarta: Raja Grafindo, 2015), h. 118
}

2. Teknik Pengambilan Sampel, adalah bagian dari populasi yang diambil dengan cara-cara tertentu dan diharapkan dapat mewakilkan populasi (representatif). Representative artinya memiliki seluruh sifat-sifat populasi meski jumlahnya lebih sedikit. Sedangkan sampling frame adalah daftar obyek yang akan diambil sampel. Daftar ini haruslah lengkap, komprehensif, dan up to date. ${ }^{29}$

Teknik pengambilan sampel pada peneliti ini menggunakan teknik Cluster Sampling. Dalam cluster sampling ini satuan sampel tidak lagi terdiri atas individu individu melainkan kelompok kelompok individu. Dan terpilih kelas VII E sebagai sampelnya. ${ }^{30}$ Teknik Pengumpulan Data;

1. Teknik Observasi, Observasi adalah teknik pengamatan secara langsung untuk menghimpun data yang diperlukan dalam penelitian dan untuk melihat keadaan kondisi tempat penelitian. Observasi yang dilakukan tidak cukup hanya sekali. Tempat yang dimaksud adalah MTs Negri 2 Kota Tangerang.

2. Studi Dokumen, Menurut Sedarmayanti dokumentasi adalah teknik pengumpulan data yang tidak langsung ditujukan pada subjek penelitian, tetapi melalui dokumen. Imam Suprayogo dokumen merupakan bahan tertulis atau benda mati yang berkaitan dengan suatu peristiwa atau aktivitas tertentu. Dokumentasi dapat berupa rekaman, dokumen tertulis seperti arsip data base, surat-menyurat, gambar, dan bendabenda peninggalan yang berkaitan

${ }^{29}$ Sarina Abdullah dan Taufik Edy Sutanto, Statistika Tanpa Stres, (Jakarta: Trans Media Pustaka, 2015), h.15

${ }^{30}$ Sugiyono, Metode Penelitian Kuantitatif, h. 136 
$\begin{array}{lrr}\text { dengan } & \text { suatu } & \text { peristiwa. }{ }^{31} \text { Dalam } \\ \text { penelitian } & \text { ini } & \text { dokumen yang }\end{array}$ digunakan berupa prestasi belajar siswa kelas VII pada mata pelajaran fikih yang telah dibukukan, gambar yang diambil saat proses penelitian berlangsung, serta foto atau gambar saat pengisian angket.

3. Teknik Angket, Teknik angket adalah teknik pengumpulan data yang dilakukan dengan cara memberi seperangkat pertanyaaan atau pernyataan tertulis kepada responden untuk dijawabnya. ${ }^{32}$

\section{Hasil Penelitian Dan Pembahasan}

1. Langkah-Langkah Antisipasi Jika Facebook Digunakan Oleh Siswa/i Kelas VII di MTs Negeri 2 Kota Tangerang

Dalam penelitian yang dilakukan oleh penulis di MTs Negeri 2 Kota Tangerang, Penulis menemukan beberapa temuan hasil penelitian, yaitu cara dalam mengantisipasi penyalah gunaan facebook dan manfaat facebook sebagai media KBM. LangkahLangkah Antisipasi Penyalah Gunaan Pemakaian Facebook:

a. Setiap guru dan disetiap sekolah diwajibkan memiliki akun facebook baru, khusus untuk program ini.

b. Guru bersangkutan melakukan berbagai settingan/pengaturan privasi di facebooknya agar hanya bisa diakses oleh siswa/siswi kelas yang ia tanganin.

c. Guru wajib menguplod ringkasan materi pelajaran hari ini di halaman facebook. Dan membahas soal-soal yang dianggap penting.

d. Setiap selesai mengajar di kelas, guru disarankan memberikan PR melalui

${ }^{31}$ Mahmud, Metode Penelitian Pendidikan, (Bandung: CV Pustaka Setia, 2011), h.58

32 Nurudin, Pengantar Komunikasi Masa, (Jakarta: Rajawali Press, 2013), h. 167. halaman facebooknya.

e. Guru bisa menetapkan dan mengumumkan jadwal onlinenya ke siswa / siswinya.

f. Guru setiap saat bisa memberikan motivasi dan inspirasi terhadap siswa/siswinya dengan mengirimkan kata-kata, gambar, presentasi, atau tokoh-tokoh sukses yang bisa memotivikasi para siswa.

2. Manfaat Facebook Jika Ditinjau Sebagai Media Dalam KBM Siswa/i di MTs Negeri 2 Kota Tangerang

a. Membentuk komunitas pendidikan.

b. Memberi informasi penting untuk siswa seputar pembelajarn dan Pendidikan.

c. Wahana untuk memberikan pesan positif untuk siswa.

d. Tempat memberikan tugas guru kepada muridnya.

e. Tempat melaporkan tugas siswa.

f. Tempat memberikan informasi berupa kisi-kisi soal.

g. Sarana untuk memberikan dukungan kepada temannya yang ikut lomba.

h. Tempat pengumuman nilai hasil ulangan.

3. Prestasi Belajar Fikih Siswa/i Kelas VII di MTs Negeri 2 Kota Tangerang

Berdasarkan penelitian ini dapat membuktikan adanya pengaruh facebook terhadap prestasi belajar fikih siswa kelas VII di MTs Negri 2 Kota Tangerang. Hal ini berdasarkan analisis data yang diperoleh dari uji normalitas, uji homogenitas, uji korelasi, uji regresi linier sederhana antar variable. Adapun hasil dari uji homogenitas adalah 0,516>0,05 maka distribusi data homogeny, hasil dari uji korelasi 0,98 lebih > 0,312 maka Ha diterima, dan uji regresi linier sederhana dari variable $\mathrm{x}$ dan $\mathrm{y}=2,7989+0,9524$, sedangkan uji 
hipotesis dengan uji $\mathrm{t}$, thitung lebih besar dari ttabel yaitu thitung 34 dan ttabel 2,021

\section{E. Kesimpulan}

Berdasarkan perhitungan penelitian ini berhasil menerima hipotesis penelitian yang menyatakan adanya Pengaruh facebook terhadap prestasi belajar siswa kelas VII pada mata pelajaran fikih di MTs Negeri 2 Kota Tangerang.

1. Guru bersangkutan melakukan berbagai settingan/pengaturan privasi di facebooknya agar hanya bisa diakses oleh siswa/siswi kelas yang ia tanganin. Dan guru wajib menguplod ringkasan materi pelajaran hari ini di halaman facebook. Dan membahas soal-soal yang dianggap penting.

2. Manfaat facebook ditinjau sebagai KBM yaitu memberikan informasi positif untuk siswa atau siswinya dan memberikan tugas kepada siswanya melalui pesan atau grup facebook.

3. Berdasarkan penelitian ini dapat membuktikan adanya pengaruh facebook terhadap prestasi belajar fikih siswa kelas VII di MTs Negri 2 Kota Tangerang.

\section{DAFTAR PUSTAKA}

Andi Wicaksono, Bahaya facebook, (Solo: Serikat Penerbit Islam, 2009)

Hasan Febriyanto Fuad, "Efektivitas Jejaring Sosial Facebook Sebagai Media Dakwah (Studi Terhadap Facebook Yusuf Mansur Network)", Skripsi, Jurusan Komunikasi dan Penyiaran Islam Fakultas Dakwah dan Komunikasi UIN, Sunan Kalijaga Yogyakarta 2013.

Martono, Nanang, "Metode Penelitian Sosial (Konsep-konsep kunci)" (Jakarta, PT. Raja Grafindo Persada).
Mahmud, Metode Penelitian Pendidikan, (Bandung: CV Pustaka Setia, 2011)

Nurudin, Pengantar Komunikasi Masa, (Jakarta: Rajawali Press, 2013)

Nurul Anisa. Penggunaan Jejaring Sosial "facebook" Terhadap Minat Belajar PAI Siswa kelas VIII SMP Negeri Yogyakarta, Skripsi, Jurusan Pendidikan Agama Islam Fakultas Ilmu Tarbiyah dan Keguruan UIN Sunan Kali jaga Yogyakarta, 2013.

Priyatna Haris, Sukses di Era Facebook, (Bandung: Kelompok pustaka hidayah)

Redja Mudyaharjo, Pengantar Pendidikan (Jakarta: PT.Raja Grafindo, 2001)

Rully Nasrullah, Media Sosial: Perspektif Komunikasi, Budaya, dan Sosioteknologi, (Bandung, Simbiosa Rekatama Media,2015)

Rosli Mohammad, Audit Komunikasi: Pendekatan dan Metode Asesmen Sistem Informasi, Komunikasi dalam organisasi, (Jakarta: Pranamedia Group, 2015).

Sartika Kurniali, Step By Step Facebook, (Jakarta: PT Elex Media Komputindo,2009

Sardiman, Interaksi dan Motivasi Belajar Mengajar, (Jakarta: Rajawali Pers)

Sugiyono, Metode Penelitian Kuantitatif, (Bandung: Alfabeta), 2018.

Suryani \& Hendryadi, Metode Riset Kuantitatif, Teori dan Aplikasi Pada Penelitian Bidang Manajemen dan Ekonomi Islam, (Jakarta: Pranamedia Group, 2015)

S Margono, Metode Penelitian Pendidikan, (Jakarta: Raja Grafindo, 2015)

Sarina Abdullah dan Taufik Edy Sutanto, Statistika Tanpa Stres, (Jakarta: Trans Media Pustaka, 2015).

Zaenal Arifin, Evaluasi Pembelajaran, (Jakarta: Dirjen Pendidkan Islam, 2009) 
Pengaruh Facebook Terhadap Prestasi Belajar Fikih Siswa Kelas Vii Di Mts Negeri 2 Kota Tangerang 